\title{
Agreement on Trade Related Aspects of Intellectual Property Rights and China's Technology Strategy
}

\author{
Yan Li, Yi Sui, Qing-bo Huang* \\ Transportation Management College, Dalian Maritime University, Dalian, Liaoning Province, China \\ liyan@dlmu.edu.cn; 476953607@qq.com; hqb4950@126.com
}

\begin{abstract}
Agreement on Trade Related Aspects of Intellectual Property Rights(TRIPs) is the first to use the name of international laws to require the WTO members to supply the effective procedures of the intellectual property rights. This throws great challenges towards its protection, technology exploration, technology transfer, etc., and it is of great meaning to China's technology strategy.

Index Terms - intellectual property rights(IPR), technology innovation, strategy

The history of the world economy and trade proves that the science and technology development which is caused by knowledge innovation and transfer is the main drive of the productive force. With the close contact of the technology and the economic developments, international society perceives clearly that each country's different protection standards of the intellectual property rights and the related laws implementations are meaningful for the economic developments.
\end{abstract}

\section{The Birth of TRIPs}

The term of "knowledge industry" was first proposed by American economist Flize Marcolupe in 1962. The knowledge economy, which is different from the economy of wealth source mainly from capital and energy, develops very quickly. The knowledge economy has put a great influence on the international trade. Since 1970s, the trade related to intellectual property rights increasingly developed with the problems aroused at the same time. For instance, in the trade appeared thousands of such violating rights as fake patent and trade mark right which brought a series of dispute on the intellectual property rights and therefore hinder the normal IPR-related trade. Therefore, the problems about IPR, especially the protection of IPR in the tangible commercial trade, are greatly valued in every country esp. in the developed countries.

The international community has established a series of international convention and International Intellectual Property Rights Organization, but the effects are not so satisfactory in that the contracting party to a treaty are limited, every country has its own law system and these laws have great difference in protection scope, degree and deadline of IPR respectively, so it lacks of unified problem-solving organization in the convention. The scientific and technological developed countries led by the US in which the protection of IPR is not only proposed in their native law but put them into WTO motion in order to keep the advantage of IPR in international trade. Through tough negotiation, each acceding party present in the ministerial conference signed 'Agreement on trade related aspects of intellectual property rights, i.e. TRIPs' in Morogo in April 15,1994.The TRIPs as one part of the file in Uruguay Round negotiation will be effective since July 1st,1995. The assignment of TRIPs marked a new area that has been developed in WTO.

\section{The Influence of TRIPs}

A. Reduction of the Distortion and Barriers in International Trade

Due to the different regulation in the field of intellectual property rights in the international trade as well as the variation of the protection levels, there are many fake and copy productions, which do great harm to the benefits of the original designers or inventors; thus, trade frictions in intellectual property rights increase continuously, which makes the trades of intellectual property rights can not be done smoothly. TRIPs are totally different from the previous regulations in this field, making the lowest standards in unification of the laws and the regulated procedures among so many countries; therefore, it reduces the frictions in this aspect.

B. The Effective and Comprehensive Protection of the Intellectual Property Rights

For a long time, the trade rates of those related with intellectual property rights versus the world trades in knowledge economy developed countries have increased year by year. In contrast, the intellectual property rights in comparably economy retarded countries have not protected well enough, and the infringement of rights has been deteriorating, with the lost 80 billion dollars per year in the world. It is calculated that the share of the infringement trades versus the world trades is $5 \%-8 \%$. Thus, TRIPs are made on the base of the developed countries' situations, although they are the lowest requirements for WTO members, among which the intellectual property rights in developed countries are protected well; meanwhile, it overpasses the actual protection in this field and the technology levels in many countries, who accept this regulation under pressure.

C. The Assurance of the Implemetation and Procedure of Property Rights Doing No Barriers to the Legal Trade TRIPs not only give the lowest requirements of the laws

Fund Program: Liaoning province social science fund project (L14AJY001): Liaoning province fund project of finance scientific research (14D008); B asic scientific research fund project of central university (3132015052) 
for each country's intellectual property rights, but also regulate the intellectual property rights demand principle for the procedure implementations in the countries at the III Part, i.e., the implementation procedures are fair without the barriers for the legal commercial trade. The detailed items are as follows: it should be charged too high; it should not conclude the unreasonable time limits; it should not be retarded without guaranteeing; it is required when the party concerned be informed, the written notice is needed; the commercial secrets of the party concerned are to be protected, etc.

\section{The Formation of the Agreeable Environment of Technology Transfer and Developments}

The increasing level of IPR protection will significantly enhance the companies in developing countries to gain technology by means of joint venture or other commercial ways. The studies showed that the IPR Level has also become an important variable in other industry and technology transfer strategy, especially in the manufacturing industry that is easy to copy such as the electronic product and computer. The effective protection of IPR will be able to increase the amount of patent register in the developing countries member. At present, most of the studies were continued and finished in the native country, but the increase of protection degree of IPR will encourage the foreign partners to do more researches and developments in the joint venture in developing countries.

\section{TRIPs and China's strategy}

With the fast increasing rate of the export and import trade in China, the problem of intellectual property rights is becoming urgent. After China's entrance into WTO, that has become a big challenge for companies when confronting with the international competitions. The open-up policy of China has absorbed a bundle of foreign companies, which have taken advantage of intellectual property rights to take up China's market, which has limited the developments of the national economy and China's companies. Internationally, with the trade liberalization pushed by WTO as well as the coming of western developed countries' knowledge economy, the intellectual property right problem has transferred from the pure law problem into a complex one closely related with the economy, politics, and diplomatic. Thus, it is needed to think about the problem in a strategic view.

\section{A. The Persistency in Improvements of the Independent Developments}

With the consideration of many problems concerning the intellectual property, we can see that the foreign investors are going to compete mainly on the export of patents and the control of the technique. In IT industry, IBM, HP and other enterprises have fundamentally taken up the hi-tech market and held most of the patents; therefore, China has to pay the patent charges. For its cell phone manufacturing industry and that can be quite a sum. According to incomplete inspection, $90 \%$ of the patents in Chinese industrial area had been caught first by foreign investors since 1996. Compete on patents did not only bring them the major part of the profit but also enable them to set or modify the industrial regulations while not being judged as doing monopoly. In some certain industries, the domestic brand got great impact as their ability of independent development was tampered; meanwhile, the trans-national organizations strengthened their control in every possible way. The international companies can take control of some domestic industries and carry out monopoly in domestic market by competing in intellectual property rights and patents.

Meanwhile, "refocusing strategy" of international companies shows more and more obvious trends, for core technology can not be imported and the international companies consider that as most important assets and keep that as secrets. Without innovation, we just follow the modes of "importing-falling behind-importing again", and we can never get out of the trap of importing and leave the promise of industrial competition capability alone. Thus, we have to strive for importing the advanced technology, and then digest and absorb it, and innovate more.

It is supposed to focus on the independent developments of new technology with the advantage of the science and research. It requires us to consolidate the absorption of high technology continuously, making great efforts on the own core technology of intellectual property rights, and improve the technology proportion in the products. At the same time companies have to emphasize more on the research staff, provide them with wonderful living and working environment, and with high salary absorb the needed specialists to enrich the research staff.

Strengthening the cooperation between companies is essential. The number of companies in China is huge but the scale is comparably small; as a result, the research ability is diverging. Thus the companies in similar lines are necessary to intensify the research cooperation, which would stipulate the quick step of developments in technology tapping and technology level as well as make full use of the original advantage of the companies each.

B. The Utilization of the International Company Technology Overflowing Phenomenon and the Practice in the Improvement of Technology and Managing Level

It is important for absorbing the related specialists. The international companies are the main pushing power for globalization, and controls $80 \%$ of the world innovation and technology transfer. If we encourage specialists in and abroad to get jobs in the international companies' China mechanisms, which is good for the combination of their knowledge, thoughts, culture and the local situations, as well as the cooperation between them and the colleges, research centers and companies, which is no doubt for pushing the technology overflowing.

Taking advantage of the brain flowing phenomenon is also very important. As the above mentioned, it is natural for the flowing of members working in China for the international companies, and the colleges, research centers, home companies, etc. The experience shows that the flowing of the specialists is the most important way for improving the 
technology innovation at the international cooperation branches overseas. The high increase of the economy in Japan and Korea, comparably big parts of the managing staff in the home companies were from the international company local branches or the technology departments of foreign companies. Those people brought advanced technology and managing experience to their country's companies or research organs, which greatly influenced the ability of innovation. And this kind of phenomenon is occurring very often in China.

\section{Developing the Cluster Effect for Pushing China's Innovation System}

As to the developing countries, the only way for lessening the difference is the improvements of innovation. In the industrial clusters, the building of technology and science innovation platform is the right point for the realization of the strategy of industrial clusters. As the core of the platform, the innovation centers of the clusters with comparably high competence are sharing the important places, which are to be built focally. Different clusters can be done according to their specialty to form the scientific innovation center, i.e., it can be done through the joint effect from the related behaviour body in the cluster, or it can depend on some big company. Companies put the innovation fruits into production, which is the main force of cluster technology innovation, which is pushing the level of the cluster technology innovation.

\section{Enhancing Intellectual Property Protection}

The protection of intellectual property is an important content of building innovation-oriented country. With the deep-going development of knowledge-based economy and economic globalization, intellectual property is becoming the strategic resources of country development and the core factor of international competitiveness. Improve the ability of the creation, utilization, protection and management of intellectual property not only can enhance China's ability of selfindependent innovation, complete the socialist market economy system, but it can also be good to improve the market competitiveness of Chinese enterprises and country's core competitiveness.

First, establish and perfect the system of intellectual property rights protection that is act on international convention. Participate actively in the formulation of technical standard nationwide and worldwide, striving for the combination of independent innovation, patent for invention and formulation of standardization so that it can create better condition for enterprise products to have monopolistic market. Establish related strategy of applying intellectual property, use related laws and regulations effectively and protect those acquired intellectual properties of enterprise.
Second, establish incentive mechanism for talented people and further complete human resources policy. Cultivate and recommend senior talent, organize cooperation with institutions of higher education and related institutions; carry out trainings of related laws and regulations; establish management system of patents and trademarks, practice selfindependent innovation and reconstruct the superiority of intellectual property towards product research, consolidate and protect intangible assets of itself.

Third, establish intellectual property protection system effectively. It needs to establish nation-uniform trade market of technological property rights, introduce nation-uniform laws and regulations; unify management of intermediary institutions, realize to share information resources and optimize configuration, improve reasonable and ordered competitiveness of property transactions market and further complete it through the competitiveness. Establish supervised organization of intellectual property, introduce related laws and regulations so that it can guarantee intellectual property is undamaged through its use and guarantee its veracity through the assessment.

Last, strengthen the management of enterprises' intellectual property. Increase the use ratio of enterprises' existed intellectual property, enhance enterprises' ability to introduce, digest, absorb, re-innovate and integrated innovate. Make high-efficient management, control and use of intellectual property, on the basis of enterprises' technology and knowledge to realize the share of knowledge within the field, so that it can establish knowledge and technological foundation of the improvement of enterprises' independent innovation ability.

\section{References}

[1] Michael Peter, Competition Strategy, Huaxia Press, 1997.

[2] Tan Hongling, Li Fei, Policy research onscientific technology innovation based on policy, Scientific Research Management, 2014(12).

[3] Lin Kang, International Companies and Management, Foreign Economy and Trade University Press, 2000.

[4] Yang Rongzhen, WTO Rules and Analysis, People Press, 2001.

[5] Liu Jun, Introduction of WTO, Foreign Economy and Trade University Press, 2002.

[6] Liu Debiao, WTO and Multi-lateral Trade Rules , China Foreign Economy and Trade Press , 2002.

[7] Gu Xiaoyan, Liu Li, The effect of intellectual property trade towards the technological innovation of Chinese high and new technology industries, Inquity into Economic Issues, 2014(12).

[8] Feng Xiaoqing, Qiao Wenxin, The market-oriented mechanism of technological innovation and intellectual property orientation research, Contemporary Economy\& Management, 2015(01).

[9] Wen Hao, Zhang Jingxia, Chen Zhongfeng, Chinese intellectual property protection and technological innovation-empirical analysis based on industry characteristics, Macroeconomic Study, 2014(11). 